\title{
PEMBINAAN OLIMPIADE MATEMATIKA SISWA SMP SWASTA NAMIRA ISLAMIC SHOOL MEDAN
}

\author{
Tanti Jumaisyaroh Siregar \\ Universitas Muslim Nusantara (UMN) Al-Washliyah \\ Jl. Garu II No. 93 Medan \\ Pendidikan Matematika \\ tanti.jss@gmail.com
}

\begin{abstract}
Abstrak
Olimpiade matematika merupakan sebuah kegiatan yang rutin diikuti oleh setiap kabupaten/ kota setiap tahunnya khususnya dinas pendidikan kota Medan. Oleh karena itu, setiap SMP Di Kota Medan mempersiapkan siswa-siswinya untuk mengikuti kegiatan OSN Matematika tersebut dimana salah satunya SMP Swasta Namira Islamic School Medan. Pelajaran matematika di SMP Swasta Namira Islamic School Medan hanya diperoleh siswa pada saat jam pelajaran sekitar 4-6 jam pelajaran kemudian ditambah dengan kegitan les matematika tambahan sekitar 2 jam pelajaran setiap minggunya. Dengan demikian, kemampuan siswa SMP Swasta Namira Islamic School Medan untuk mengikuti kegiatan olimpiade matematika masih kurang. Hal ini berdasarkan masih minimnya partisipasi dan prestasi siswa dalam mengikuti kegiatan olimpiade matematika. Oleh karena itu, perlu dilakukan pembinaan khusus olimpiade matematika bagi siswa-siswi SMP Swasta Namira Islamic School Medan. Adapun jenis pembinaan olimpiade matematika yang akan diberikan yaitu program pembinaan dengan struktur program $30 \%$ pemantapan teori, $50 \%$ latihan soal, dan sisanya $20 \%$ wawancara atau moderasi. Tujuannya adalah untuk meningkatkan kemampuan siswa dalam memahami dan menyelesaikan soal-soal olimpiade matematika sehingga dapat meningkatkan prestasi siswa dalam kegiatan olimpiade matematika yang akan diadakan tahun depan.
\end{abstract}

Kata Kunci : Olimpiade, Matematika, Siswa-siswi

\begin{abstract}
Mathematics olympiad is an activity that routinely followed by every regency / city every year especially education department of Medan city. Therefore, every Junior High School in Medan prepares its students to join the OSN Mathematics activities where one of them is SMP Namira Islamic School Medan. The math lesson at SMP Namira Islamic School Medan was obtained by students during the lesson time of about 4-6 hours lessons and then the lesson added with additional mathematics tutoring about 2 hours of lessons each week. Thus, the ability students of SMP Namira Islamic School Medan to follow of mathematics olympiad is still low. This matter based the participation and the achievement of students in following the mathematics olympiad event are still low. Therefore, it is necessary to do special coaching mathematics olympics for students of SMP Namira Islamic School Medan. The type of guidance mathematics olympiad that will be given is a program of guidance with the structure of the program $30 \%$ stabilization theory, $50 \%$ exercise questions, and the remaining $20 \%$ interview or moderation. The goal is to improve students' ability in understanding and solving mathematics olympiad problems so as to improve student achievement in mathematics olympiad event which will be held next year.
\end{abstract}

Keywords: Olympic, Mathematics, Students

\section{PENDAHULUAN}

Matematika merupakan salah satu mata pelajaran wajib yang diberikan kepada siswa mulai dari tingkat dasar sampai tingkat perguruan tinggi. Matematika mengajarkan dan melatih siswa untuk berpikir secara logis, kritis, kreatif dan aktif (Susanto, 2013:183). Selama ini, matematika banyak menjadi momok bagi siswa dimana banyak siswa yang tidak menyukai pelajaran matematika. Sebagian siswa 
menganggap bahwa matematika merupakan pelajaran yang sulit. Namun, bagi sebagian yang lain matematika merupakan pelajaran yang menyenangkan dan menantang. Pada umumnya siswa yang menyukai pelajaran matematika memiliki kemampuan matematika yang lebih baik jika dibandingkan siswa lainnya.

Siswa-siswa yang menyukai mata pelajaran matematika tersebut menjadi perhatian khusus oleh pemerintah dimana pemerintah berusaha mewadahi kemampuan matematika siswa melalui Jendral Pendidikan Dasar dan Menengah bekerja sama dengan Dinas Pendidikan Kab/Kota dan juga beberapa Perguruan Tinggi menyelenggarakan olimpiade matematika pada tahun 2003 hingga sekarang. Olimpiade matematika merupakan salah satu cara untuk mengukur kemajuan dan mengetahui posisi mutu pendidikan khususnya bidang studi matematika suatu sekolah di suatu daerah (Wahyudi, I., dan Kawuwung, W.B, 2016:60). Salah satu jenis kegiatan olimpiade matematika yang dilaksanakan adalah olimpiade sains nasional (OSN). Adapun tujuan dilaksanakannya OSN adalah untuk menjajal kemampuan matematika siswa SMP dan mencari siswa-siswa yang unggul dalam pelajaran matematika baik di daerah maupun kota untuk mengikuti kompetisi olimpiade matematika pada tingkat Internasional.

(Mamlukat, 2009 :1).

Berdasarkan tujuan tersebut maka OSN SMP khususnya bidang studi matematika merupakan sebuah kegiatan yang rutin diikuti oleh setiap kabupaten/ kota setiap tahunnya khususnya dinas pendidikan kota Medan. Oleh karena itu, setiap SMP di Kota Medan mempersiapkan siswa- siswinya untuk mengikuti kegiatan OSN Matematika tersebut dimana salah satunya SMP Swasta Namira Islamic School Medan.

SMP Swasta Namira Islamic School Medan berlokasi di Jl. Setia Budi Pasar I No. 76 Tanjung Sari, Kecamatan Medan Selayang, Kota Medan. SMP Swasta Namira Islamic School Medan memiliki beberapa kegiatan ekstrakurikuler seperti pramuka, futsal, menari, speaking club, science club, drum band dan renang. Dari kegiatan ekstrakurikuler tersebut dapat dilihat bahwa belum ada kegiatan yang mewadahi olimpiade matematika di sekolah tersebut.

Pelajaran matematika hanya diperoleh siswa pada saat jam pelajaran sekitar 4-6 jam pelajaran kemudian ditambah dengan kegitan les matematika tambahan sekitar 2 jam pelajaran setiap minggunya. Dengan demikian, kemampuan siswa SMP Swasta Namira Islamic School Medan untuk mengikuti kegiatan olimpiade matematika masih kurang. Hal ini berdasarkan masih minimnya partisipasi dan prestasi siswa dalam mengikuti kegiatan olimpiade matematika. Selain itu, siswa SMP Swasta Namira Islamic School Medan lebih tertarik mengikuti olimpiade Bahasa Inggris dan IPA dibandingkan matematika. Hal ini terbukti setiap tahunnya siswa SMP Swasta Namira Islamic School Medan mendapat peringkat 30 besar se- Sumatera Utara dalam olimpiade Bahasa Inggris dan IPA sedangkan pada olimpiade matematika tidak pernah mencapai peringkat tersebut.

Oleh karena itu, perlu
dilakukan olimpiade matematika bagi siswa-siswi SMP Swasta Namira Islamic School Medan yang memiliki kemampuan dan ketertarikan terhadap kegiatan olimpiade matematika diluar jam pelajaran dan les tambahan matematika yang diberikan di sekolah. Adapun jenis pembinaan olimpiade matematika yang akan diberikan yaitu program pembinaan dengan struktur program $30 \%$ pemantapan teori, $50 \%$ latihan soal, dan sisanya $20 \%$ wawancara atau moderasi. Berdasarkan hasil penelitian Astawa (2007) model pembinaan tersebut mampu meningkatkan kemampuan akademik calon peserta OSN Matematika.

Berdasarkan uraian di atas, penulis bermaksud akan melakukan pengabdian masyarakat dalam bentuk pembinaan dan pelatihan soal-soal 
olimpiade matematika bagi siswa-siswi SMP Swasta Namira Islamic School Medan. Pembinaan yang dilakukan sebagai upaya pengabdian yang di lakukan oleh dosen dalam menyebarkan ilmu sehingga bermanfaat secara langsung, di pihak lain sekolah memerlukan pembinaan intensif guna menghadapi OSN. Tujuannya adalah untuk meningkatkan kemampuan siswa dalam memahami dan menyelesaiakan soal-soal olimpiade matematika sehingga dapat meningkatkan prestasi siswa dalam kegiatan olimpiade matematika yang akan diadakan tahun depan. Akhirnya, semoga pembinaan dan pelatihan olimpiade matematika ini dapat memberi bekal bagi siswa SMP Swasta Namira Islamic School Medan untuk lebih termotivasi dan giat mempelajari matematika.

Berdasarkan uraian masalah yang dihadapi di atas, maka adapun pendekatan pemecahan masalah yang akan dilakukan adalah dengan mengadakan pengabdian dalam bentuk pembinaan dan pelatihan kepada siswasiswi SMP Swasta Namira Islamic School Medan. Adapun materi yang akan disampaikan oleh pemateri adalah soal-soal olimpiade matematika tingkat kota, tingkat provinsi maupun tingkat nasional beserta penyelesaiannya.

\section{METODE PELAKSANAAN}

Pelaksanaan program IbM ini dilaksanakan sebagai upaya memotivasi siswa dalam mengikuti kegiatan olimpiade matematika siswa dan sebagai upaya melatih kemampuan siswa dalam memahami dan menyelesaikan soal-soal olimpiade matematika. Solusi yang ditawarkan adalah pembinaan dan pelatihan kepada siswa-siswi SMP Swasta Namira Islamic School Medan.

Prosedur kegiatan program IbM yang diusulkan dalam usulan ini meliputi tahapan: (1) persiapan, (2) pelaksanaan, (3) observasi dan evaluasi, (4) penulisan laporan, (5) diseminasi.

\section{HASIL}

Kegiatan program IbM ini adalah berupa kegiatan pembinaan dan pelatihan olimpiade matematika telah dilaksanakan pada hari Selasa, tanggal 29 November 2016 yang bertempat di salah satu kelas SMP Swasta Namira Islamic School Medan yang beralamat di Jl. Setia Budi Pasar I No.76 Tanjung Sari Medan. Selanjutnya, peserta yang hadir dalam kegiatan pembinaan dan pelatihan olimpiade matematika tersebut adalah siswa-siswi SMP Swasta Namira Islamic School Medan yang berjumlah 21 orang.

Pada kegiatan pembinaan dan pelatihan olimpiade matematika tersebut dibuka oleh wakil kepala sekolah/PKS I sekaligus merupakan guru matematika SMP Swasta Namira Islamic School Medan yaitu Bapak Yasir Fuad, S.Pd yang berlangsung sekitar 15 menit dari pukul 09.00 sampai pukul 09.15 wib. Selanjutnya, pembina memberikan motivasi kepada siswa untuk berminat dan tertarik mengikuti olimpiade mateatika baik tingkat kota, provinsi maupun nasional. Kegiatan memotivasi siswa tersebut berlangsung selama 15 menit yaitu pada pukul 09.15-09.30 wib. Setelah itu, pembina memberikan pematapan teori selama 50 menit yaitu pada pukul 09.30 sampai 10.20 wib.

Selanjutnya,

pembina memberikan soal latihan kepada siswa untuk dikerjakan siswa baik secara mandiri maupun diskusi selama 60 menit. Kemudian soal dibahas bersama- sama dengan pembina dimana pembina meminta beberapa orang siswa menuliskan jawabannya di papan tulis selama 30 menit. Secara keseluruhan kegiatan latihan soal ini berlangsung selama 90 menit pada pukul 10.20 - 11.50 wib.

Selanjutnya, pada kegiatan akhir pembina mewawancara beberapa orang siswa terkait dengan kegiatan pembinaan dan pelatihan olimpiade matematika yang telah dilakukan selama 30 menit yaitu pada pukul 11.50-12.20 dan diakhiri kegiatan 
penutup kegiatan pembinaan olimpiade matematika selama 10 menit.

Kegiatan pembinaan dan pelatihan ini berjalan cukup lancar dan telah sesuai dengan yang direncanakan. Antusiasme dari para peserta dalam pelaksanaan pembinaan dan pelatihan ini dibuktikan dengan perhatian yang diberikan peserta kepada pembina/pelatih yang tampil serta terdapat interaksi dan tanya jawab antara peserta dan pembina/pelatih.

Pemahaman materi yang disampaikan oleh pembina/pelatih juga cukup baik, meskipun ada beberapapenggunaan bahasa dalam yang agak sulit diterima oleh peserta, namun pembina/pelatih mencoba menunjukkan foto/ gambar dari bahasa yang sulitdipahami peserta. Selain itu, dengan kompetensi dan cara penyampaian materi yang baik dari pemateri akhirnya dapat dengan mudah diterima, dimengerti dan mendapat tanggapan atau apresiasi yang baik dari para peserta.

\section{KESIMPULAN}

Kesimpulan yang dapat diperoleh dari pelaksanaan program pengabdian kepada masyarakat ini adalah:

a. Pelaksanaan dari program kegiatan pembinaan/pelatihan olimpiade matematika bagi siswa SMP Swasta Namira Islamic School Medan ini sudah berjalan dengan lancar dan sesuai dengan yang diharapkan;

b. Siswa SMP Swasta Namira Islamic School Medan telah memperoleh pengetahuan yang baru mengenai cara penyelesaian soal-soal olimpiade matematika.

\section{DAFTAR PUSTAKA}

Astawa, I.W.P. 2007. Model Pembinaan Olimpiade Matematika

Sekolah Dasar di Provinsi

Bali. (Jurnal Pendidikan dan Pengajaran UNDIKSHA, No.2). (http://pasca.undiksha.ac.id/im ages/img_item/744.doc,diakses 7 Oktober 2016).

Mamlukat. I. 2009. Menjadi Juara Olimpiade Matematika SMP. Jakarta: Media Pusindo.
Susanto, A. 2013. Teori Belajar dan Pembelajaran di Sekolah Dasar. Jakarta : Kencana Prenada Media Grup.

Wahyudi, I. dan Kawuwung,W.B. 2016. Pembinaan Olimpiade Matematika Pada Guru Bidang Studi Matematika Sekolah Menengah Atas di Kota Jayapura. (Jurnal Pengabdian Papua,Vol,No.2). (http://ejournal.unicen.ac.id/ind ex.php/JPP2/article/download/ 381/342, diakses 14 Oktober 2016).

Wahyuddin. 2016. Pengaruh Metakognisi, Motivasi Belajar dan Kreativitas Belajar Terhadap Kemampuan Pemecahan Masalah Siswa Kelas VIII SMP Negeri 2 Sabangparu Kabupaten Wajo. (Jurnal Daya Matematis, Vol.4 No.1).(http://ojs.unm.ac.id/inde x.php/JDM/article/view/2453, diakses 7 Juli 2016). 